\section{Non-classic congenital adrenal hyperplasia. Clinical experience versus clinical guidelines}

\author{
Amy S. Shah, Philippe F. Backeljauw \\ Division of Endocrinology, Cincinnati \\ Children's Hospital Medical Center, \\ University of Cincinnati College of \\ Medicine, Cincinnati, $\mathrm{OH}$, USA
}

\section{Abstract}

The ability to diagnose non-classic congenital adrenal hyperplasia (NC-CAH) has improved drastically over the past decade due to standardization of laboratory assays and refinement of molecular studies. However, the optimal clinical management for this patient population is still evolving. Thus, we describe the clinical presentation and diagnostic approach of children with non-classic congenital adrenal hyperplasia (NC-CAH). A retrospective chart review was done to identify all subjects diagnosed with late-onset $\mathrm{CAH}$ or NC$\mathrm{CAH}$ at a single institution during the last decade. Eighteen subjects were identified. Fourteen were diagnosed as NC-CAH 21hydroxylase deficiency and four with NC-CAH 3-beta hydroxysteroid dehydrogenase (3ßHSD) deficiency. The approach to evaluation was different according to the provider. Re-evaluation of steroid hormone concentrations using updated diagnostic criteria revealed one patient had ACTH-stimulated hormone concentrations consistent with classic CAH (non-salting wasting variant) and four patients initially thought to have NC-CAH $3 \beta$ HSD had steroid hormone concentrations consistent with premature adrenarche. Age and clinical presentation did not differentiate subjects with NC-CAH from those with premature adrenarche. Skeletal age was $\geq$ to 2 standard deviations advanced only in those patients with NC-CAH. Variations in the diagnostic approach to evaluate children for NCCAH exist. We provide a practical algorithmic recommendation, incorporating the most recent diagnostic guidelines, to aid the clinician in the evaluation of this disorder.

\section{Introduction}

The ability to diagnose non-classic congenital adrenal hyperplasia (NC-CAH) has improved drastically over the past decade due to standardization of laboratory assays and refinement of molecular studies. However, optimal clinical management for this patient population is still evolving and only recently have evidence-based guidelines for the diagnosis of NC-CAH been published. ${ }^{1}$

The diagnosis of NC-CAH encompasses a number of adrenal enzyme deficiencies causing excessive androgen secretion with onset in childhood. This disorder is estimated to be prevalent in $0.1-3 \%$ of the general population, $, 2,3$ although studies in more select groups report a prevalence of up to $10 \%{ }^{4}$ While 21 hydroxylase enzyme deficiency (21-OHD) accounts for up to $90 \%$ of cases of NC-CAH, deficiencies in the other adrenal enzymes such as 3 beta-hydroxysteroid dehydrogenase (3ßHSD) and 11 beta-hydroxylase deficiency (11 $\beta-0 H D)$ can rarely occur. ${ }^{3-5}$

The diagnosis of NC-CAH is not always easily established. The clinical presentation may be asymptomatic or may mirror premature adrenarche (PA) in childhood and polycystic ovarian syndrome or functional ovarian hyperandrogenism in adolescence, as the degree of androgen excess varies widely in these patient groups. ${ }^{3,6}$ The gold standard for differentiating between the different adrenal enzyme defects is the adrenocorticotropic hormone (ACTH) stimulation test with measurement of basal and stimulated adrenal steroid concentrations. ${ }^{4,5,7,8}$ Using long established criteria, ACTH stimulation testing does not always lead to a clear diagnosis. For example, there exists significant overlap in both basal and ACTHstimulated steroid concentrations for patients with NC-CAH $3 \beta \mathrm{HSD}$ and PA.9-12 Finally, although molecular testing for NC-CAH is now available, it is not always routinely used, at least in part because of its high cost and inadequate of insurance coverage.

The aim of this study was to review the clinical experience with NC-CAH at Cincinnati Children's Hospital Medical Center (CCHMC) during the last decade. We suspected that, even with the availability of hormone-genotype correlation testing, there would still be variations in the diagnostic approach of this disorder. Thus, the purposes of this study were to i) Describe the clinical presentation of our patients diagnosed with NC-CAH; ii) Review the diagnostic criteria used in the work-up of NC-CAH; and iii) Provide a practical algorithm to aid in the clinical evaluation of this disorder.

\section{Materials and Methods}

\section{Subjects}

The study was approved by the Institutional Review Board at CCHMC. Retrospective chart review was done on all patients with a diagnosis of NC-CAH/ late-onset CAH followed in the endocrine clinic at CCHMC during the last decade. Patients were identified from medical
Correspondence: Amy S Shah, Division of Endocrinology, Cincinnati Children's Hospital Medical Center, 3333 Burnet Avenue, MLC 7012, Cincinnati OH 45229, USA.

Tel: +1:513.636.7033 - Fax +1.1513.636.4786

E-mail: amy.shah@cchmc.org.

Key words: pediatrics, non-classic congenital adrenal hyperplasia, 21-hydroxylase deficiency, 3beta hydroxysteroid dehydrogenase deficiency

Conflict of interest: the authors report no conflicts of interest.

Received for publication: 6 September 2011. Accepted for publication: 11 October 2011.

This work is licensed under a Creative Commons Attribution NonCommercial 3.0 License (CC BYNC 3.0).

(C) Copyright A.S. Shah and P.F. Backeljauw, 2011 Licensee PAGEPress, Italy

Endocrinology Studies 2011; 1:e11

doi:10.4081/es.2011.e11

records bearing the diagnostic code of adrenogenital disorder/CAH (ICD-9 code 255.2). Subjects with with evidence of central precocious puberty at diagnosis (females with breast development before the age of 8 years and males with testicular enlargement before the age of 9 years) were excluded from this analysis. Recorded parameters included: age, pubertal staging, laboratory data, skeletal age radiographs and treatment as documented by the treating endocrinologist.

Similarly, retrospective chart review was conducted on children with the diagnosis of PA during the same time frame. This population served as a control group. An equal number of patients were reviewed for age at presentation, clinical signs and symptoms, laboratory data and skeletal age radiographs.

\section{Hormone assays}

All patients had basal steroid measurements done. A standard ACTH corticotrophin stimulation test was done in the morning (before 10.00 a.m.) at the discretion of the evaluating endocrinologist. Blood samples were obtained before and $60 \mathrm{~min}$ after corticotropin 0.25 $\mathrm{mg} / \mathrm{m}^{2}$ was given as a slow intravenous bolus. With the exception of cortisol (C), which was assayed directly on aliquots of diluted serum, all other steroid hormones, including serum 17- hydroxyprogesterone (17-0HP), 17-hydroxypregnenolone $(\Delta 5-17 \mathrm{P})$, dehydroepiandrosterone (DHEA), dehydroepiandrosterone sulfate (DHEA sulfate) and androstenedione ( $\Delta 4$ A) were analyzed by a combination of extraction and chromatographic purification (13, 14). All samples were sent to Esoterix, Inc for evaluation. 


\section{Diagnosis of adrenal enzyme deficiency}

Prior to characterizing this population, the authors wanted to ensure each subject truly had the disorder. Based on the most recent literature, $1,15-20$ the following steroid hormone concentrations were used to classify the subjects: i) Heterozygote Carrier 21-0HD; baseline $17-0 \mathrm{HP}<200 \mathrm{ng} / \mathrm{dL}(6 \mathrm{nmol} / \mathrm{L})$, and ACTH- stimulated 17-0HP < $1666 \mathrm{ng} / \mathrm{dL}$ (50 $\mathrm{nmol} / \mathrm{L})$; ii) NC-CAH 21-0HD, Baseline 17OHP > $200 \mathrm{ng} / \mathrm{dL}(6 \mathrm{nmol} / \mathrm{L})$, and ACTH-stimulated 17-0HP between 1000-10,000 ng/dL (31$300 \mathrm{nmol} / \mathrm{L}$ ); iii) Classic Simple Virilizing (CSV) 21-0HD, baseline 17-0HP > $200 \mathrm{ng} / \mathrm{dL}$ (6 $\mathrm{nmol} / \mathrm{L})$, and ACTH-stimulated 17-0HP > $10,000 \mathrm{ng} / \mathrm{dL}(300 \mathrm{nmol} / \mathrm{L})$; iv) $\mathrm{NC}-\mathrm{CAH}$ $3 \beta \mathrm{HSD}$, ACTH- stimulated $\Delta 5-17 \mathrm{P} \geq 6678 \mathrm{ng} / \mathrm{dL}$ (201 nnol/L) and $\Delta 5-17 \mathrm{P}$ to $\mathrm{C}$ ratio $\geq 363$.

\section{Results}

Eighteen subjects (10 males, 8 females) were identified on retrospective review labeled as having NC-CAH or late-onset $\mathrm{CAH}$. Demographics, skeletal age, clinical information and laboratory data are presented in Table 1. Fourteen subjects had been diagnosed with NC-CAH 21-OHD and four subjects with NCCAH $3 \beta$ HSD. After the authors' review of basal and ACTH-stimulated steroid concentrations from initial diagnosis, one patient was subsequently re-classified as C-SV 21-OHD.1,21,22 Seven subjects had not undergone ACTH-stimulation testing and therefore re-classification was not possible. The four subjects originally diagnosed with NC-CAH $3 \beta$ HSD were no longer believed to have this disorder when newer criteria for diagnosing NC-CAH 3 $3 \mathrm{HSD}$, which is based on genotype-hormone correla- tions, were applied.18,19 These four subjects were re-classified as $\mathrm{PA}$.

The mean age at presentation for all subjects was 8 years \pm 3 years 2 months (range 3 15 years). When assessed by our re-classification method, the average age of presentation for the NC-CAH 21-OHD group was 8 years 7 months \pm 3 years 2 months. This group had an average skeletal age advancement of 4 years \pm 2 year 1 month. Eleven of those with NC-CAH 21-0HD presented with premature pubarche, pubic hair Tanner stage II-IV, while two patients presented with a single complaint of either excessive acne or clitoromegaly. No patients had clinical or biochemical evidence of salt wasting.

Eleven patients had undergone ACTH stimulation testing (Table 1). For those in the NCCAH 21-OHD group, all had basal 17-0HP concentrations > $200 \mathrm{ng} / \mathrm{dL}(6 \mathrm{nmol} / \mathrm{L})$ with ACTHstimulated values, when obtained, $>1,000$

Table 1. Clinical and laboratory data for children after re-classification.

\begin{tabular}{|c|c|c|c|c|c|c|c|c|}
\hline n & Sex & $\begin{array}{c}\text { CA } \\
\text { (years) }\end{array}$ & $\begin{array}{l}\text { Skeletal age } \\
\text { (years) }\end{array}$ & $\begin{array}{c}\text { Clinical } \\
\text { presentation }\end{array}$ & $\begin{array}{c}\Delta 5-17 \mathrm{P} \\
(\mathrm{ng} / \mathrm{dL}) \\
0^{\prime} \\
60^{\prime}\end{array}$ & $\begin{array}{c}\text { 17-0HP (ng/dL) } \\
\text { (ng/dL) } \\
0^{\prime} \\
60^{\prime}\end{array}$ & $\begin{array}{c}\text { DHEA } \\
\text { (ng/dL) } \\
0^{\prime} \\
60^{\prime}\end{array}$ & $\begin{array}{c}\text { A } \\
\text { (ng/dL) } \\
0^{\prime} \\
60^{\prime}\end{array}$ \\
\hline \multicolumn{9}{|c|}{ 'NC-CAH 21-0HD } \\
\hline 1 & $\mathrm{~F}$ & 5 years 2 months & 7 years 10 months & T3 PH & $\begin{array}{l}- \\
-\end{array}$ & $\begin{array}{l}3340 \\
6950\end{array}$ & $\begin{array}{l}777 \\
837\end{array}$ & $\begin{array}{l}176 \\
238\end{array}$ \\
\hline 2 & $\mathrm{~F}$ & 7 years 9 months & 10 years & T2 PH & $\begin{array}{l}227 \\
638\end{array}$ & $\begin{array}{l}1110 \\
3500\end{array}$ & $\begin{array}{l}284 \\
319\end{array}$ & $\begin{array}{l}82 \\
88\end{array}$ \\
\hline 3 & M & 8 years 2 months & 10 years & T3 PH & $\begin{array}{c}177 \\
1297\end{array}$ & $\begin{array}{l}1160 \\
6310\end{array}$ & $\begin{array}{l}224 \\
401\end{array}$ & $\begin{array}{l}122 \\
122\end{array}$ \\
\hline 4 & $\mathrm{~F}$ & 15 years 6 months & - & Acne, hirsuitism & $\begin{array}{l}2037 \\
3928 \\
\end{array}$ & $\begin{array}{l}1900 \\
4290\end{array}$ & $\begin{array}{l}- \\
-\end{array}$ & $\begin{array}{l}- \\
-\end{array}$ \\
\hline 5 & M & 8 years 2 months & 13 years & T3 PH & $\begin{array}{l}- \\
-\end{array}$ & $\begin{array}{l}4260 \\
5030\end{array}$ & $\begin{array}{c}951 \\
1209\end{array}$ & $\begin{array}{l}223 \\
241\end{array}$ \\
\hline 6 & M & 9 years & 13 years & $\begin{array}{c}\text { T4 PH } \\
1746\end{array}$ & $\begin{array}{l}1046 \\
8709\end{array}$ & $\begin{array}{l}7249 \\
1417 \\
\end{array}$ & $\begin{array}{l}905 \\
235\end{array}$ & 181 \\
\hline 7 & $\mathrm{~F}$ & 15 years 10 months & - & Clitoromegaly & - & $\begin{array}{c}1330 \\
-\end{array}$ & - & $\begin{array}{c}483 \\
-\end{array}$ \\
\hline 8 & M & 7 years 4 months & 12 years 6 months & T2 PH & - & $\begin{array}{c}1631 \\
-\end{array}$ & $\begin{array}{c}135 \\
-\end{array}$ & $\begin{array}{c}169 \\
-\end{array}$ \\
\hline 9 & M & 10 years & 13 years & T3 PH & $\begin{array}{l}- \\
-\end{array}$ & $\begin{array}{c}1036 \\
-\end{array}$ & $\begin{array}{l}- \\
-\end{array}$ & $\begin{array}{c}137 \\
-\end{array}$ \\
\hline 10 & M & 6 years & 13 years & T3 PH & - & $\begin{array}{c}4630 \\
-\end{array}$ & - & - \\
\hline 11 & M & 3 years 10 months & 11 years & T3 PH & $\begin{array}{l}- \\
-\end{array}$ & $\begin{array}{c}7900 \\
-\end{array}$ & $\begin{array}{l}- \\
-\end{array}$ & - \\
\hline 12 & M & 7 years 7 months & 13 years 6 months & T3 PH & - & $\begin{array}{c}9260 \\
- \\
\end{array}$ & - & $\begin{array}{c}242 \\
- \\
\end{array}$ \\
\hline 13 & $\mathrm{~F}$ & 7 years 2 months & 9 years & T3 PH & $\begin{array}{l}- \\
-\end{array}$ & $\begin{array}{c}4170 \\
-\end{array}$ & - & $\begin{array}{c}104 \\
-\end{array}$ \\
\hline & cted & AH 21-0HD now S & 21-0HD & & & & & \\
\hline 14 & $\mathrm{~F}$ & 5 years 2 months & 8 years 10 months & T3 PH & $\begin{array}{l}1269 \\
1615\end{array}$ & $\begin{array}{c}5608 \\
10441\end{array}$ & $\begin{array}{c}1456 \\
951\end{array}$ & $\begin{array}{l}219 \\
208\end{array}$ \\
\hline
\end{tabular}

M, male; F, female; CA, chronological age; T, tanner staging; PH, pubic hair; NC-CAH, non-classic congenital adrenal hyperplasia; 21-OHD, 21-hydroxylase enzyme deficiency; 17-OHP, 17- hydroxyprogesterone; $\triangle$ 5-17P, 17-hydroxypregnenolone; DHEA, dehydroepiandrosterone. 0 ' and 60 minute ACTH stimulation values. To convert to Standard International units multiply $\triangle 5$-17P, 17-OHP, DHEA, and A by 0.03. 
Table 2. Laboratory data of the four patients suspected of non-classic congenital adrenal hyperplasia 3-beta hydroxysteroid dehydrogenase (NC-CAH 3 $\beta$ HSD).

\begin{tabular}{|c|c|c|c|c|c|c|c|}
\hline n & Sex & $\begin{array}{l}\text { Clinical } \\
\text { presentation }\end{array}$ & $\begin{array}{l}\text { Steroid con } \\
\text { using older eval } \\
\text { Ratio } \Delta 5-17 \mathrm{P} / \\
17-0 H \mathrm{P} \text { (ng/dL) } \\
0^{\prime} \\
60^{\prime}\end{array}$ & $\begin{array}{l}\text { ns } \\
\text { iteria9-12,23 } \\
\text { Ratio } \\
\text { DHEA/A } \\
0^{\prime} \\
60^{\prime}\end{array}$ & $\begin{array}{l}\text { based } \\
\Delta 5-17 \mathrm{P} / \mathrm{C} \\
(\mathrm{nmol} / \mathrm{L}) \\
0^{\prime} \\
60^{\prime}\end{array}$ & $\begin{array}{l}\text { id concent } \\
\text { newer eval } \\
\text { Cortisol } \\
\text { (umol/L) } \\
0^{\prime} \\
60^{\prime}\end{array}$ & $\begin{array}{l}\text { Rs } \\
\text { Ratio } \\
\Delta 5-17 \mathrm{P} / \mathrm{C} \\
0^{\prime} \\
60^{\prime}\end{array}$ \\
\hline 15 & F & T3 PH, acne & $\begin{array}{l}2.5 \\
9.7\end{array}$ & $\begin{array}{l}4.6 \\
8.8\end{array}$ & $\begin{array}{l}17.1 \\
34.4\end{array}$ & $\begin{array}{l}0.4 \\
0.9\end{array}$ & $\begin{array}{l}43.4 \\
38.0\end{array}$ \\
\hline 16 & M & Acne & $\begin{array}{l}1.9 \\
-\end{array}$ & $\begin{array}{l}5.4 \\
8.3\end{array}$ & $\begin{array}{c}2.5 \\
41.4\end{array}$ & $\begin{array}{l}0.4 \\
1.3\end{array}$ & $\begin{array}{c}6.6 \\
32.6\end{array}$ \\
\hline 17 & $\mathrm{~F}$ & T3 PH & $\begin{array}{l}15.7 \\
13.1\end{array}$ & $\begin{array}{l}8.5 \\
9.7\end{array}$ & $\begin{array}{c}1.4 \\
-\end{array}$ & $\begin{array}{l}0.3 \\
0.8\end{array}$ & $\begin{array}{c}5.3 \\
-\end{array}$ \\
\hline 18 & M & T2 PH, acne & $\begin{array}{l}20.3 \\
15.7\end{array}$ & $\begin{array}{l}10.0 \\
11.4\end{array}$ & $\begin{array}{l}26.5 \\
44.6\end{array}$ & $\begin{array}{l}0.9 \\
1.1\end{array}$ & $\begin{array}{l}31.1 \\
41.3\end{array}$ \\
\hline
\end{tabular}

T, tanner staging; PH, pubic hair; 17-OHP, 17- hydroxyprogesterone; 5-17P, 17-hydroxypregnenolone; DHEA, dehydroepiandrosterone. To convert to Standard International units, multiply $\triangle 5$-17P, 17-OHP, DHEA and A by 0.03. To convert to metric units (ng/dL), multiple $\Delta 5-17 \mathrm{P}$ and $\mathrm{F}$ by 33.3 .

$\mathrm{ng} / \mathrm{dL}(31 \mathrm{nmol} / \mathrm{L})$. The one patient reclassified in the SV-CAH 21-OHD group, basal 17-0HP values was $>200 \mathrm{ng} / \mathrm{dL}(6 \mathrm{nmol} / \mathrm{L})$ with an ACTH- stimulated value $\geq 10,000 \mathrm{ng} / \mathrm{dL}$ (300 $\mathrm{nmol} / \mathrm{L})$. The four patients originally diagnosed as NC-CAH $3 \beta$ HSD had elevated ACTH -stimulated $\triangle 5$-17P and DHEA concentrations, and ratios of $\Delta 5$-17P to $17-0 H P$ or DHEA to $\Delta 4$ A >2 standard deviations (SDS) above the mean for age or pubertal stage of normal subjects, and met previously established diagnostic criteria. ${ }^{9-12,23}$

However, when these four patients were reassessed with newer diagnostic criteria for NC-CAH 33HSD (evaluation by ACTH- stimulated $\Delta 5-17 \mathrm{P}$ and $\Delta 5-17 \mathrm{P}$ to $\mathrm{C}$ ratio), using the lowest absolute hormone concentrations for genotype-confirmed $3 \beta \mathrm{HSD}$, their steroid concentrations did not meet the criteria, thus these patients were re-classified as premature adrenarche ${ }^{18,19}$ (Table 2).

Treatment regimens for all subjects are listed in Table 3. Thirteen patients were treated with glucocorticoid (GC) therapy to suppress adrenal androgen overproduction and protect adult height potential. The average GC dose as hydrocortisone (HC) equivalent was 12 $\mathrm{mg} / \mathrm{m}^{2} /$ day. Two patients were treated with stress dosing GC only. Three patients received no GC treatment. By sub-group, all children in the NC-CAH 21-OHD group were treated with either maintenance or stress dosing GC. Only one patient in the presumed NC-CAH $3 \beta$ HSD group was being treated with GC. None of the subjects identified on retrospective review had undergone molecular testing.

Data from a similar size control group $(n=14)$ consisting of children with PA were also reviewed (details not shown). Included in this group were the 4 children initially classified as NC-CAH $3 \beta \mathrm{HSD}$. Twelve presented with premature pubarche pubic hair tanner stage IIIII, while two presented with a single complaint of excessive acne or early axillary hair growth. The average age of presentation was 6 years 9 months \pm lyear 5 months. Skeletal age advancement was lyear 5 months \pm 1 year. In all subjects DHEA sulfate and 17-0HP steroid concentrations were normal for pubertal/tanner stage consistent with the diagnosis of premature adrenarche and did not overlap with those in the NC-CAH groups.

\section{Discussion}

We reviewed the clinical presentation and diagnostic evaluation of 18 patients initially diagnosed with NC-CAH at our institution during the last decade. Within our large endocrine group ( $n=10)$ we demonstrate heterogeneity in the diagnostic process. All patients, based on their late clinical presentation, were initially diagnosed as late-onset $\mathrm{CAH}$ or NC-CAH. Only eleven underwent ACTH stimulation testing. On our repeat assessment of their basal and ACTH- stimulated steroid concentrations we found one subject with steroid concentrations consistent with SV-CAH 21-OHD.13 Four patients initially diagnosed as NC-CAH $3 \beta \mathrm{HSD}$ had to be re-classified as having PA using newer diagnostic criteria. Finally, when treatment approaches were reviewed we found 13 subjects were treated with maintenance steroids, two with stress dose GC alone and three who were not treated at all. We suspect these variations in care are due to overlap in the clinical presentation of NC-CAH with PA and ovarian hyperandrogenism, non-adherence to the newer diagnostic criteria, and lack of confirmatory genetic testing.

The clinical presentation was similar in all subjects regardless of diagnosis, indicating that premature pubarche alone does not distinguish patients with NC-CAH from those with PA. Skeletal age determination was helpful. All subjects in the NC-CAH group had skeletal
Table 3. Treatment information.

\begin{tabular}{|c|c|}
\hline Patient & $\begin{array}{l}\text { Hydrocortisone } \\
\text { equivalent }+ \\
\text { Co-therapy }\end{array}$ \\
\hline $1^{*}$ & $9-18.5 \mathrm{mg} / \mathrm{m}^{2} /$ day. \\
\hline $2^{*}$ & $12.5-19.5 \mathrm{mg} / \mathrm{m}^{2} /$ day. \\
\hline $3^{*}$ & 13-19 mg/m²/day. \\
\hline 4 & Stress doses only. \\
\hline 5 & $3 \mathrm{mg} / \mathrm{m}^{2} /$ day. \\
\hline 6 & Stress doses only \\
\hline 7 & $5 \mathrm{mg} / \mathrm{m}^{2} /$ day. \\
\hline $8^{*}$ & $\begin{array}{l}13 \mathrm{mg} / \mathrm{m}^{2} / \text { day }+ \\
\text { fludrocortisone } 0.1 \mathrm{mg} / \text { day. }\end{array}$ \\
\hline 9* & $\begin{array}{l}12.5 \mathrm{mg} / \mathrm{m}^{2} / \mathrm{day}+ \\
\text { fludrocortisone } 0.1 \mathrm{mg} / \text { day. }\end{array}$ \\
\hline 10 & $4 \mathrm{mg} / \mathrm{m}^{2} /$ day. \\
\hline $11^{*}$ & $\begin{array}{l}\quad 8-15 \mathrm{mg} / \mathrm{m}^{2} / \text { day }+ \\
\text { fludrocortisone } 0.05 \mathrm{mg} / \text { day. }\end{array}$ \\
\hline $12 *$ & $\begin{array}{l}\quad 8-13 \mathrm{mg} / \mathrm{m}^{2} / \text { day }+ \\
\text { fludrocortisone } 0.1 \mathrm{mg} / \text { day. }\end{array}$ \\
\hline $13^{*}$ & $\begin{array}{l}\qquad 15 \mathrm{mg} / \mathrm{m}^{2} / \text { day }+ \\
\text { fludrocortisone } 0.1 \mathrm{mg} / \text { day. }\end{array}$ \\
\hline $14^{*}$ & $\begin{array}{l}15 \mathrm{mg} / \mathrm{m}^{2} / \text { day }+ \\
\text { fludrocortisone } 0.1 \mathrm{mg} / \text { day. }\end{array}$ \\
\hline $15 / 16 / 17$ & None \\
\hline 18 & $15 \mathrm{mg} / \mathrm{m}^{2} /$ day. \\
\hline
\end{tabular}

* Those also receiving GnRH-agonist therapy during treatment.

advancement of $\geq 2$ SDS for age whereas those subjects with PA on average had skeletal ages within 2 SDS of the mean, a finding consistent with previous reports. ${ }^{24-27}$ ACTH stimulation testing would have been helpful. Studies have shown basal 17-0HP to be a reliable screening tool for the diagnosis of late-onset 21-0HD $5,8,15$ but in instances where C-SV may be suspected, ACTH stimulation testing helps to differentiate between C-SV and NC-CAH. This distinction is important as long term treatment differs between these two groups. In our study, $4 / 7$ subjects in the NC-CAH 21-OHD group had 
basal 17-0HP concentrations $\geq$ than 3500 $\mathrm{ng} / \mathrm{dL}(105 \mathrm{nmol} / \mathrm{L})$ suggestive of C-SV. ${ }^{28}$ In these patients, ACTH stimulation testing may have been helpful to exclude this diagnosis. However, it was not done.

ACTH stimulation testing has also been shown to be helpful in the diagnosis of NC$\mathrm{CAH} 3 \beta \mathrm{HSD}$. In the last decade the diagnosis of NC-CAH due to $3 \beta$ HSD has been optimized. Prior diagnostic criteria were based on elevated ACTH-stimulated $\Delta 5-17 \mathrm{P}$ to $17-0 H P$ or DHEA to $\Delta 4$-A ratios. ${ }^{9-12,23}$ However, when considerable overlap in the hormone concentrations of subjects with and without mutations in the $3 \beta \mathrm{HSD}$ gene were found, ${ }^{14,18,19}$ newer criteria were proposed. ${ }^{18,19}$ It was first suggested that ACTH stimulated $\Delta 5-17 \mathrm{P}$ and $\Delta 5-17 \mathrm{P}$ to $\mathrm{C}$ ratio more accurately predict $3 \beta \mathrm{HSD}$ deficiency. 18 These data were refined by Mermejo et al providing hormone concentration cutoffs when the diagnosis of NC-CAH $3 \beta$ HSD should be considered. ${ }^{19}$ These data should now be used as standard for the diagnosis for NC-CAH 33HSD.

When the treatment choices were reviewed in our study, 13 children were treated with an average of $12 \mathrm{mg} / \mathrm{m}^{2} /$ day of $\mathrm{HC}$ equivalent. Five were also treated with fludrocortisone. This

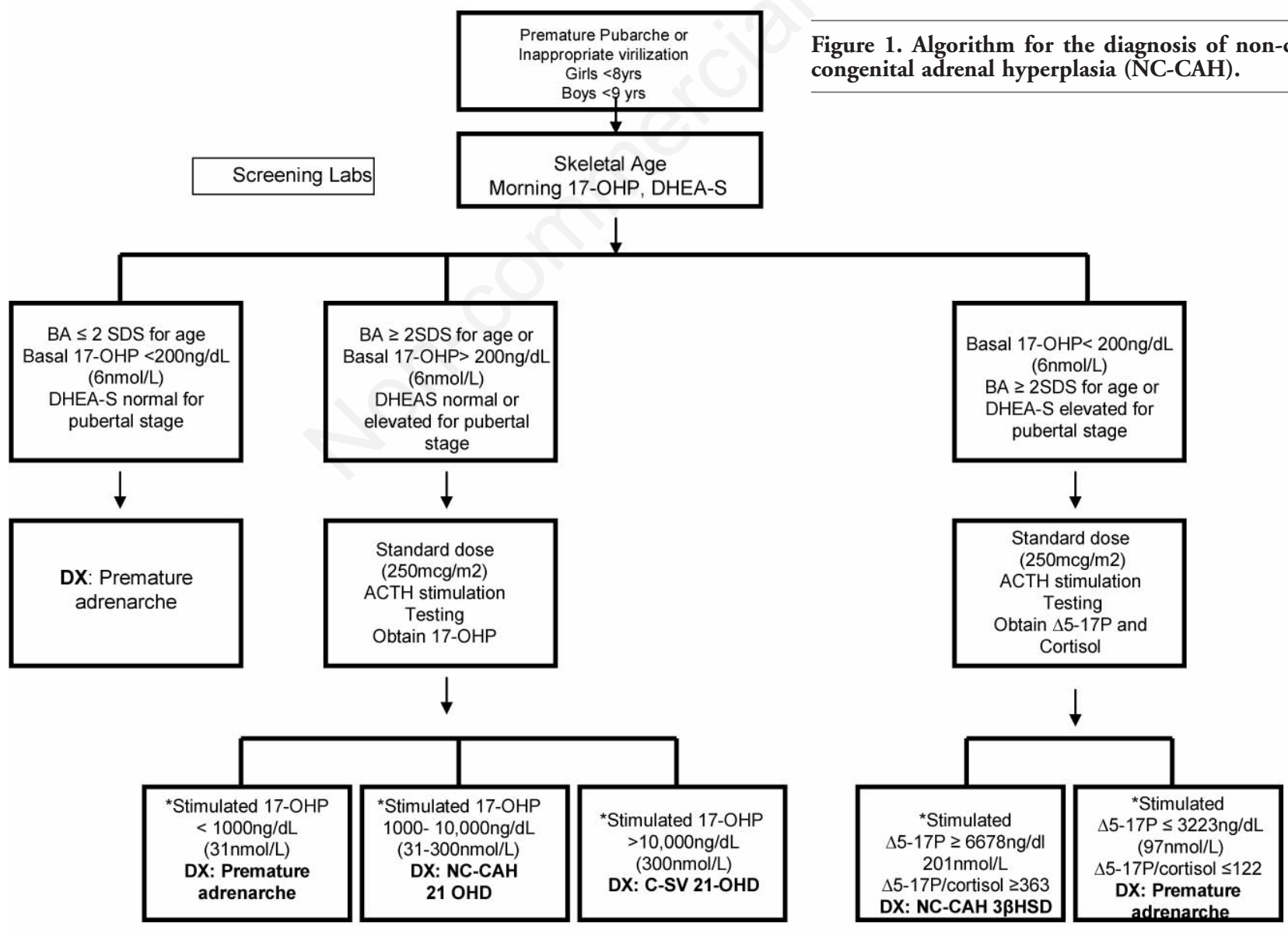

variable approach is likely due paucity of longterm outcome data in this population. Although the recommendations are not clear as to when to treat with glucocorticoids, advancement of skeletal age and adult height protection are accepted indications. Use of stress dosing is advocated in NC-CAH when adrenal function is suboptimal or iatrogenically suppressed. ${ }^{1}$

There is significant overlap in the clinical presentation of patients with NC- CAH (21OHD or $3 \beta \mathrm{HSD}$ ) and PA. For that reason, we recommend using the laboratory cutoffs as outlined by Speiser et al in the Endocrine Society's 2010 Clinical Practice Guidelines for the diagnosis of CAH. ${ }^{1}$ In addition, we advocate the use of a skeletal age film and a morning DHEA sulfate (Figure 1). DHEA sulfate is a useful screening test to exclude primary adrenal disorders.

To accurately differentiate between the types of NC-CAH, ACTH stimulation testing is needed. Basal and ACTH- stimulated concentrations of 17-0HP should be obtained during ACTH stimulation testing along with $\triangle 5-17 \mathrm{P}$ and $\mathrm{C}$. This will not only diagnose NC-CAH 21$\mathrm{OHD}$, but allow one to differentiate it from $\mathrm{C}$ $\mathrm{SV}$, and to also differentiate NC-CAH $3 \beta \mathrm{HSD}$ from PA. Special attention must be applied to NC-CAH $3 \beta$ HSD to avoid false positives. ACTHstimulated $\triangle 5-17 \mathrm{P}$ concentrations $\geq 6678 \mathrm{ng} / \mathrm{dL}$ $(201 \mathrm{nmol} / \mathrm{L})$ and a $\Delta 5-17 \mathrm{P}$ to $\mathrm{C}$ ratio $\geq 363$ should be used for the diagnosis NC-CAH 3 $\beta$ HSD. On the other hand, ACTH-stimulated values of $\Delta 5-17 \mathrm{P} \leq 3,223 \mathrm{ng} / \mathrm{dL}(97 \mathrm{nmol} / \mathrm{L})$ and a $\Delta 5-17 \mathrm{P}$ to $\mathrm{C}$ ratio $\leq 122$ should exclude this diagnosis. These laboratory cutoffs are generated from the lowest ACTH stimulated $\Delta 5-17 \mathrm{P}$ concentrations and $\Delta 5-17 \mathrm{P}$ to $\mathrm{C}$ ratios assessed in genotype-confirmed subjects, as well as the highest ACTH stimulated values from genotype-negative subjects. ${ }^{18,19}$ In our four patients with suspected NC-CAH $3 \beta \mathrm{HSD}$, these diagnostic criteria would have effectively ruled out this disorder. A narrow range still exists between these cutoff values wherein the diagnosis remains unclear. For those subjects, we would recommend molecular testing to confirm or exclude the diagnosis of NC-CAH $3 \beta$ HSD.

Although molecular testing is available for the diagnosis of the different adrenal enzyme deficiencies causing NC-CAH, these tests can not always be obtained. There is a high cost associated with genetic testing. Insurance coverage for genotyping is often lacking or

$\mathrm{BA}=$ bone age, $\mathrm{SDS}=$ standard deviations, $17-\mathrm{OHP}=17$-hydroxyprogesterone, $\mathrm{DHEAS}=$ dehydroepiandrosterone sulfate, $\triangle 5-17 \mathrm{P} 17$-hydroxypregnelone, $\mathrm{DX}=\mathrm{Diagnos}$ is $\mathrm{NC}-\mathrm{CAH}=$ Non- Classic Congenital Adrenal hyperplasia, C-SV=Classic simple virilizing, $21-\mathrm{OHD}=21$-hydroxylase deficiency, $3 \beta \mathrm{HSD}=3$ beta hydroxysteroid dehydrogenase deficiency. ${ }^{*}$ Criteria adapted from Lutfallah, Mermejo, and Speiser et al. 
patients have very high co-payments preventing this testing to be used on a routine basis. Furthermore, patients may be apprehensive to participate in DNA studies. For these reasons, laboratory evaluation is still the primary means for diagnosis of these disorders in many situations.

The retrospective nature of this study resulted in some missing data. Because not all children underwent ACTH stimulation testing reclassification could not be done in all instances. Additionally, we can not confirm with certainty the diagnosis, as molecular analysis was not done. However, our reclassification methods were based on established diagnostic criteria1,15-20 and therefore likely represent an accurate diagnosis.

In conclusion, significant variations in care regarding the evaluation of $\mathrm{NC}-\mathrm{CAH}$ exist. We have proposed a practical evaluation algorithm for the diagnosis of NC-CAH to help in the diagnosis of NC-CAH 21-OHD and eliminate erroneous classification of NC-CAH $3 \beta \mathrm{HSD}$. In situations when the diagnosis is unclear, ACTH stimulation testing should be part of the workup. Genotyping should be attempted when the results of ACTH stimulation testing are equivocal or for the purposes of genetic counseling. ${ }^{1}$ Practitioners managing patients with NC-CAH should, in light of the more recent hormonal and genetic information and practice guidelines as well, review their previously made diagnoses, especially for patients with NC-CAH $3 \beta$ HSD. Future studies are still needed to evaluate the long term outcomes for these disorders and to determine the best therapeutic strategies for this heterogeneous group of patients.

\section{References}

1. Speiser PW, Azziz R, Baskin LS et al. Congenital adrenal hyperplasia due to steroid 21-hydroxylase deficiency: an Endocrine Society clinical practice guideline. J Clin Endocrinol Metab 2010;95: 4133-60.

2. Escobar-Morreale HF, Sanchon R, San Millan JL. A prospective study of the prevalence of nonclassical congenital adrenal hyperplasia among women presenting with hyperandrogenic symptoms and signs. J Clin Endocrinol Metab 2008;93: 527-33.

3. Speiser P, Brenner D. Congential Adrenal Hyperplasia Resulting from 21
Hydroxylase Deficiency. The Endocrinologist 2003;13:334-40.

4. Azziz R, Dewailly D, Owerbach D. Clinical review 56: Nonclassic adrenal hyperplasia: current concepts. J Clin Endocrinol Metab 1994;78:810-5.

5. Azziz R. 21-Hydroxylase- Deficient Nonclassic Adrenal Hyperplasia. The Endocrinologist 1995;5:297-303.

6. Fanta M, Cibula D, Vrbikova J. Prevalence of nonclassic adrenal hyperplasia (NCAH) in hyperandrogenic women. Gynecol Endocrinol 2008;24:154-7.

7. Panitsa-Faflia C, Batrinos ML. Late-onset congenital adrenal hyperplasia. Ann N Y Acad Sci 1997;816:230-4.

8. Azziz R. Nonclassic adrenal hyperplasia. Curr Ther Endocrinol Metab 1997;6:175-8.

9. Eldar-Geva T, Hurwitz A, Vecsei P et al. Secondary biosynthetic defects in women with late-onset congenital adrenal hyperplasia. N Engl J Med 1990;323:855-63.

10. Lobo RA, Goebelsmann U. Evidence for reduced 3 beta-ol-hydroxysteroid dehydrogenase activity in some hirsute women thought to have polycystic ovary syndrome. J Clin Endocrinol Metab 1981;53:394-400.

11. Pang S. Congenital adrenal hyperplasia owing to 3 beta-hydroxysteroid dehydrogenase deficiency. Endocrinol Metab Clin North Am 2001;30:81-99.

12. Pang SY, Lerner AJ, Stoner E et al. Lateonset adrenal steroid 3 beta-hydroxysteroid dehydrogenase deficiency. I. A cause of hirsutism in pubertal and postpubertal women. J Clin Endocrinol Metab 1985;60:428-39.

13. Esoterix Endocrinology Syllabus. 2007. Available from: http://www.esoterix.com/ education/healthpro/endocrinology.shtml

14. Sakkal-Alkaddour H, Zhang L, Yang $X$ et al. Studies of 3 beta-hydroxysteroid dehydrogenase genes in infants and children manifesting premature pubarche and increased adrenocorticotropin-stimulated delta 5-steroid levels. J Clin Endocrinol Metab 1996;81:3961-5.

15. Armengaud JB, Charkaluk ML, Trivin C et al. Precocious pubarche: distinguishing late-onset congenital adrenal hyperplasia from premature adrenarche. J Clin Endocrinol Metab 2009;94:2835-40.

16. Bachega TA, Billerbeck AE, Marcondes JA et al. Influence of different genotypes on 17-hydroxyprogesterone levels in patients with nonclassical congenital adrenal hyperplasia due to 21-hydroxylase deficiency. Clin Endocrinol 2000;52:601-7.
17. Bidet M, Bellanne-Chantelot C, GalandPortier MB et al. Clinical and molecular characterization of a cohort of 161 unrelated women with nonclassical congenital adrenal hyperplasia due to 21-hydroxylase deficiency and 330 family members. J Clin Endocrinol Metab 2009;94:1570-8.

18. Lutfallah C, Wang W, Mason JI et al. Newly proposed hormonal criteria via genotypic proof for type II 3beta-hydroxysteroid dehydrogenase deficiency. J Clin Endocrinol Metab 2002;87:2611-22.

19. Mermejo LM, Elias LL, Marui S et al. Refining hormonal diagnosis of type II 3beta-hydroxysteroid dehydrogenase deficiency in patients with premature pubarche and hirsutism based on HSD3B2 genotyping. J Clin Endocrinol Metab 2005;90:1287-93.

20. Wilson RC, Mercado AB, Cheng KC, New MI. Steroid 21-hydroxylase deficiency: genotype may not predict phenotype. J Clin Endocrinol Metab 1995;80:2322-9.

21. New MI, Lorenzen F, Lerner AJ et al. Genotyping steroid 21-hydroxylase deficiency: hormonal reference data. J Clin Endocrinol Metab 1983;57:320-6.

22. Speiser PW, White PC. Congenital adrenal hyperplasia. N Engl J Med 2003;349:77688.

23. Temeck JW, Pang SY, Nelson C, New MI. Genetic defects of steroidogenesis in premature pubarche. J Clin Endocrinol Metab 1987;64:609-17.

24. Ibanez L, Virdis R, Potau N et al. Natural history of premature pubarche: an auxological study. J Clin Endocrinol Metab 1992;74:254-7.

25. Pang S. Premature adrenarche. Pediatr Adolesc Endocrinol 1984;13:173-84.

26. Pang S. Premature Thelarche and Premature Adrenarche. Pediatr Ann 1981; 10:340-5.

27. Reiter E SP. Premature adrenarche. The Endocrinologist 1997;7:85-8.

28. Witchel SF, Nayak S, Suda-Hartman M, Lee PA. Newborn screening for 21-hydroxylase deficiency: results of CYP21 molecular genetic analysis. J Pediatr 1997;131:32831.

29. Latronico AC, Chrousos GP. Neoplasms of the adrenal cortex. Clinical and basic aspects. Cancer Treat Res 1997;89:217-37.

30. Ghizzoni L, Mastorakos G, Vottero A. Adrenal hyperandrogenism in children. $\mathrm{J}$ Clin Endocrinol Metab 1999;84:4431-5. 